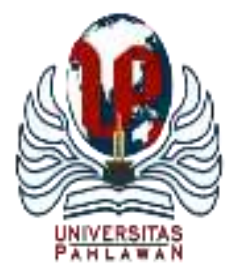

Edukatif : Jurnal Ilmu Pendidikan Volume 4 Nomor 1 Tahun 2022 Halm 970 - 983 EDUKATIF: JURNAL ILMU PENDIDIKAN

Research \& Learning in Education

https://edukatif.org/index.php/edukatif/index

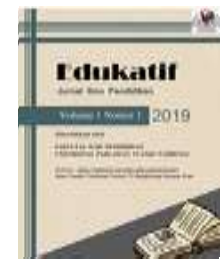

\title{
Peningkatan Pemahaman Mahasiswa Tentang Etika Lingkungan Melalui Implementasi Merdeka Belajar dan Kampus Merdeka
}

\author{
Laila Febrina $^{1 \bowtie}$, Kholil $^{2}$, Evelyn Hanaseta $N^{3}$, Purnomosutji Dyah Prinajati ${ }^{4}$ \\ Program Studi Lingkungan Universitas Sahid Jakarta, Indonesia ${ }^{1,2,3,4}$

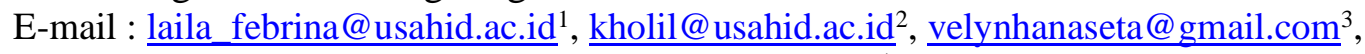 \\ iinsoekandar@gmail.com ${ }^{4}$
}

\begin{abstract}
Abstrak
Merdeka Belajar - Kampus Merdeka (MBKM) merupakan kebijakan pemerintah untuk membekali mahasiswa dengan keterampilan dan pengalaman nyata untuk memasuki pasar kerja/industri melalui experiential learning di lapangan atau di dunia industri. Program Studi Teknik Lingkungan Universitas Sahid telah mengimplementasikan kebijakan MBKM ini melalui kerjasama dan sinergi dengan lembaga mitra strategis yang bergerak di bidang lingkungan. Tulisan ini bertujuan untuk mengetahui dampak penerapan MBKM terhadap pemahaman mahasiswa terhadap pemecahan masalah lingkungan, khususnya yang berkaitan dengan kelestarian lingkungan. Pengumpulan data melalui diskusi mendalam dan wawancara kepada mahasiswa yang telah magang di industri. Analisis data yang digunakan adalah statistik deskriptif dilanjutkan dengan analisis kualitatif. Hasil penelitian menunjukkan bahwa mahasiswa yang melakukan magang di industri lingkungan menyatakan pemahamannya terhadap isu lingkungan meningkat, demikian pula kepercayaan dirinya. Selain itu, terungkap pula bahwa sistem pemagangan yang dilakukan memberikan pengalaman nyata untuk melihat permasalahan lingkungan dan membangun kesadaran diri. Oleh karena itu perlu mengajak masyarakat untuk menerapkan etika lingkungan dalam memanfaatkan sumber daya alam.
\end{abstract}

Kata Kunci: MBKM, kelestarian lingkungan, etika lingkungan, kesadaran masyarakat

\section{Abstract}

Merdeka Belajar-Kampus Merdeka (MBKM) is a government policy to equip students with real skills and experience to enter the job market/industry through experiential learning in the field or in the industrial world. The Environmental Engineering Study Program at Sahid University has implemented this MBKM policy through collaboration and synergy with strategic partner institutions engaged in the environment. This paper aims to determine the impact of implementing MBKM on students' understanding of solving environmental problems, especially those related to environmental sustainability. Data collection through discussions and indepth interviews to students who have internships in the industry. Analysis of the data used is descriptive statistics followed by qualitative analysis. The results showed that students who did internships in the environmental industry stated that their understanding of environmental issues increased, as well as their selfconfidence. In addition, it was also revealed that the apprenticeship system that was carried out provided real experience to see environmental problems and build self-awareness. Therefore, it is necessary to invite the community to apply environmental ethics in utilizing natural resources.

Keywords: MBKM, environmental sustainability, environmental ethics, public awareness.

Copyright (c) 2022 Laila Febrina, Kholil, Evelyn Hanaseta N, Purnomosutji Dyah Prinajati

$\triangle$ Corresponding author

Email : laila_febrina@usahid.ac.id

DOI : https://doi.org/10.31004/edukatif.v4i1.1941

ISSN 2656-8063 (Media Cetak)

ISSN 2656-8071 (Media Online) 
971 Peningkatan Pemahaman Mahasiswa Tentang Etika Lingkungan Melalui Implementasi Merdeka Belajar dan Kampus Merdeka - Laila Febrina, Kholil, Evelyn Hanaseta N, Purnomosutji Dyah Prinajati

DOI: https://doi.org/10.31004/edukatif.v4i1.1941

\section{PENDAHULUAN}

Mahasiswa yang dinamis, inovatif dan kreatif, merupakan sesuatu yang didambakan dalam menghadapi era digital 4.0. Keterampilan abad 21 sangat dibutuhkan untuk mensukseskan globalisasi, perubahan pasar global, kompetensi internasional, migrasi, lingkungan politik, dan perkembangan teknologi (Wahyunita \& Subroto, 2021). Langkah awal untuk mewujudkan hal tersebut adalah melalui program kegiatan merdeka belajar kampus merdeka (MB-KM). Konsep dasar MB-KM ini terinspirasi dari filsafat K.H. Dewantara dengan penekanan pada kemerdekaan dan kemandiriannya. Konsep esensial pada MB-KM ini adalah " Merdeka Belajar" dan "Kampus Merdeka”.Merdeka belajar bermakna pada kemerdekaan berfikir, yaitu suatu upaya menghormati perubahan dalam pembelajaran di lembaga pendidikan. Sementara kampus merdeka bermakna upaya untuk melepasan belenggu agar mudah untuk bergerak (Fuadi, 2021) (Rusli Baharuddin, 2021) (Dirjen Dikti Kemendikbud, 2020) . Suksesnya pendidikan juga dilihat dari seberapa besar karakter para mahasiswa ketika dapat menyeimbangkan kognitif, afektif dan psikomotornya untuk menjadi manusia yang sempurna (Wahyunita \& Subroto, 2021). Sebuah upaya untuk menghasilkan pendidikan yang baik yang tersusun sesuai rencana, maka harus memiliki strategi dalam kegiatan pembelajaran (Muthoharoh \& Sakti, 2021).

Tujuan kebijakan Merdeka Belajar Kampus Merdeka adalah mendorong mahasiswa dalam menguasai berbagai bidang ilmu pengetahuan dengan bidang keahliannya, sehingga siap bersaing dalam dunia global. Jika budaya belajar tersebut dapat diwujudkan, maka secara langsung akan meningkatkan hubungan dan kesesuaian antara kebutuhan dunia usaha dan dunia industri, sekaligus menyiapkan mahasiswa memasuki dunia kerja lebih awal sehingga dapat memangkas masa tunggu mahasiswa dalam memperoleh pekerjaan (Wahyudi et al., 2021) . Adapun bentuk kegiatan MB-KM yang dapat dipilih oleh mahasiswa secara sukarela terdiri dari 8 bentuk kegiatan yang terlihat pada Gambar 1 berikut ini (Dirjen Dikti Kemendikbud, 2020) .

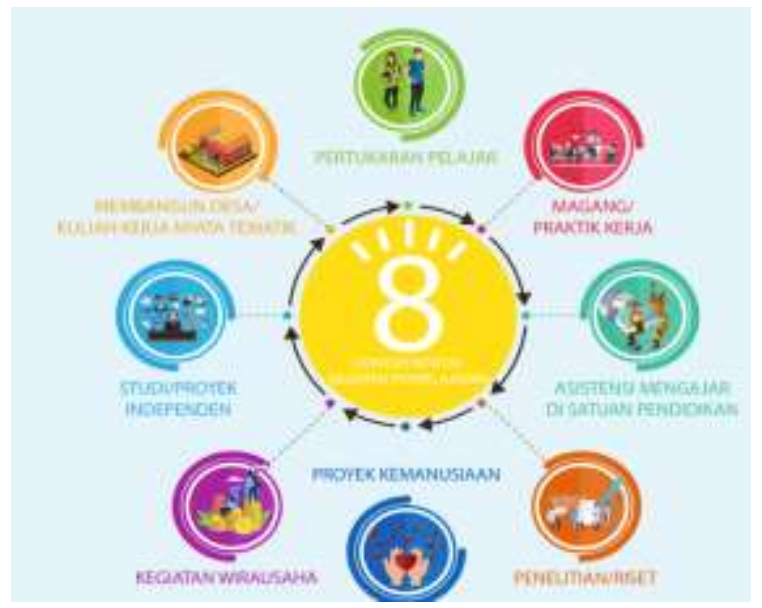

Gambar 1: Delapan Bentuk Program MB-KM

Kesiapan calon lulusan Program Teknik Lingkungan di Universitas Sahid dalam menghadapi dunia pekerjaan riil berbekal penguasaan pengetahuan keteknikan (engineering) serta Keterampilan merupakan tujuan yang senantiasa diupayakan pencapaiannya dengan lebih baik dari waktu ke waktu. Dalam rangka mempersiapkan lulusan sarjana Teknik Lingkungan yang siap pakai serta siap dikembangkan, selaras dengan salah satu bentuk program MB-KM maka dilakukan dengan magang industry, khusunya di bidang lingkungan. Melalui Magang industri di bidang lingkungan mahasiswa diharapkan akan memiliki pengalaman dalam 
972 Peningkatan Pemahaman Mahasiswa Tentang Etika Lingkungan Melalui Implementasi Merdeka Belajar dan Kampus Merdeka - Laila Febrina, Kholil, Evelyn Hanaseta N, Purnomosutji Dyah Prinajati

DOI: https://doi.org/10.31004/edukatif.v4i1.1941

menghadapi problem-problem lingkungan yang saat ini menjadi issue sentral. Magang industri merupakan upaya untuk memberikan bekal pengalaman, pengetahuan dan keterampilan kerja nyata (Samidjo, 2017).

Pelaksanaan program magang yang berbasis MBKM ini berbeda dengan praktek kerja lapangan (PKL) sebelumnya, dimana pada kegiatan magang ini mahasiswa langsung mengikuti kegiatan-kegiatan yang seharihari dihadapi oleh dunia industri di bidang lingkungan seperti masalah pencemaran lingkungan, evaluasi dampak lingkungan, pengukuran kualitas lingkungan serta menumbuhkan kesadaran masyarakata tentang pentingnya menjaga lingkungan. Mahasiswa sebagai pemuda memiliki peran sebagai agent of change. Peran dan partisipasinya sangat penting dalam membangun kesejahteraan masyarakat, sehingga tidak dapat dipungkiri bahwa setiap negara selalu berusaha untuk membangun pengetahuan, keterampilan, dan karakater pemuda.

Problem lingkungan yang paling serius saat ini adalah emisi karbon yang menyebabkan global warming. Global warming terjadinya akibat melimpahnya karbon dioksida di atmosfer sebagai gas rumah kaca yang dampaknya meningkatnya suhu bumi (Budianta, 2010)(Muhammad Rizki et al., 2016). Pemanasan global sebagai dampak dari aktifitas masyarakat dalam konsumsi energi utamanya yang berbahan bakar fosil (Purwanto, 2018). Salah faktor yang menyebabkan tinggi emisi karbon disebabkan penggunaan energi atau sumber daya yang berlebih. Hal ini disebabkan karena rendahnya kesadaran manusia terhadap lingkungan (etika lingkungan).

Keberadaan suatu lingkungan sangat bergantung pada peran etika lingkungan pada manusia. Pengelolaan lingkungan yang "nir-etik" dapat mengakibatkan pencemaran lingkungan. Artinya manusia melakukan pengelolaan lingkungan terhadap sumber daya alam yang ada tanpa menghadirkan etika lingkungan. Sumber daya alam yang utama bagi manusia adalah tanah, air, dan udara. Tanah merupakan tempat manusia untuk melakukan berbagai kegiatan. Air sangat diperlukan oleh manusia sebagai komponen terbesar dari tubuh manusia.Untuk menjaga keseimbangan, air sangat dibutuhkan dengan jumlah yang cukup banyak dan memiliki kualitas yang baik. Selain itu, udara merupakan sumber oksigen yang alami bagi pernafasan manusia. Lingkungan yang sehat akan terwujud apabila manusia dan lingkungannya dalam kondisi yang baik (Hasir \& Rofiqi, 2017).

Sebagai implementasi dari kebijakan MB-KM, mahasiswa Prodi Teknik Lingkungan Usahid telah melaksanakan magang industri di beberapa industri yang terkait dengan lingkungan (Unilab, Cogindo, RND Teknologi Bersama dll). Pada kegiatan magang tersebut, mahasiswa langsung terjun ke lapangan bersama dengan tim dari perusahaan tempat mereka magang untuk melakukan pemetaan terhadap kesadaran masyarakat di bidang lingkungan, pengukuran kualitas lingkungan.

Masalah lingkungan pada hakekatnya menjadi tanggung jawab semua orang. Dengan demikian sangat perlu adanya upaya membina wawasan dan kepedulian lingkungan di kalangan masyarakat (Julius \& Nagel, 2020). Problem utama yang mereka hadapi adalah bagaimana membangun kesadaran masyarakat dalam hal etika lingkungan untuk menjamin keberlanjutan lingkungan dan kehidupan di bumi. Dalam teori behavioristik, lingkungan merupakan sumber belajar. Orang akan bereaksi jika diberikan rangsangan oleh lingkungannya (Saihu \& Mailana, 2019).

Program MB-KM merupakan hal yang baru diluncurkan oleh Kementerian Pendidikan, Kebudayaan, Riset, dan Teknologi, karena itu pada paper ini bertujuan untuk mengetahui dampak penerapan MBKM terhadap pemahaman mahasiswa terhadap pemecahan masalah lingkungan, khususnya yang berkaitan dengan kelestarian lingkungan. Mahasiswa sebagai pemuda yang diharapkan sebagai agent of change (Sulaeman et al., 2021). Peran dan partipasi mahasiswa sangat dibutuhkan masyarakat untuk menumbuhkan kesadaran masyarakat terhadap etika lingkungan. Penelitian yang terkait peningkatan pemahaman etika lingkungan melalui program MB-KM belum banyak dibahas dalam artikel -artikel penelitian. Penelitian yang dilakukan oleh (Telly Rosdiyani et al., 2021) membahas terkait aplikasi magang industri dari sisi urgensi regulasi dari 
973 Peningkatan Pemahaman Mahasiswa Tentang Etika Lingkungan Melalui Implementasi Merdeka Belajar dan Kampus Merdeka - Laila Febrina, Kholil, Evelyn Hanaseta N, Purnomosutji Dyah Prinajati

DOI: https://doi.org/10.31004/edukatif.v4i1.1941

pelaksanaan magang, tidak membahas tentang aspek etika lingkungan dalam program magang industri sebagai salah satu implementasi MB-KM. Kajian lain berupa penelitian studi literatur tentang tantangan pengembangan kurikulum Merdeka Belajar Kampus Merdeka di perguruan tinggi yang akan diadaptasikan oleh program studi (Mariati, 2021). Adapun tujuan dari penelitian ini yaitu untuk mengetahui dampak penerapan MB-KM terhadap pemahaman mahasiswa terhadap pemecahan masalah lingkungan, khususnya yang berkaitan dengan kelestarian lingkungan.

\section{METODE PENELITIAN}

Penelitian ini dilakukan di Program Studi Teknik Lingkungan Universitas Sahid pada Bulan Desember 2022. Subyek penelitian ini adalah mahasiswa Program Studi Teknik lingkungan. Metodelogi yang dipilih pada kajian ini adalah metode deskriptif kualitatif. Pengambilan data dilakukan terhadap populasi mahasiswa di Prodi TL secara keseluruhan yang berjumlah 203 responden terkait program MB-KM melalui google form. Kemudian dilanjutkan dengan pengisian kuisioner terhadap mahasiswa yang telah melaksanakan kegiatan magang industri. Hasil dari kuisioner tersebut dieksplorasi kembali dengan wawancara dan diskusi mendalam, Hasil penelitian dianalisis secara deskriptif untuk mengetahui pemahaman mahasiswa tentang etika lingkungan melalui implementasi Merdeka Belajar dan Kampus Merdeka. Data ditampilkan dalam bentuk tabel. Analisis data dilakukan melalui statistik deskriptif yang dilanjutkan dengan analisis kualitatif

\section{HASIL DAN PEMBAHASAN PENELITIAN}

Berbagai kerusakan dan krisis lingkungan yang mencakup pencemaran (udara, air, dan tanah), terganggunya keseimbangan rantai makanan, menipisnya sumber daya alam bumi dan cadangan energi, penipisan lapisan ozon, pemanasan global, dan lain sebagainya membutuhkan upaya penanganan dan pengelolaan yang dalam rangka penanggulangan dampak negatif kegiatan manusia yang bertujuan untuk meningkatkan mutu lingkungan (Muhammad Taufik Awaludin, 2017). Peran akademisi, industri dan pemerintah sangat diharapkan dapat mengupayakan terjadinya pembangunan yang berkelanjutan yang memeprhatikan kelestarian lingkungan. Perguruan tinggi sebagai lembaga tinggi juga memiliki peranan penting dalam upaya pengelolaan lingkungan dan upaya mengatasi penurunan kualitas lingkungan. Hal penting yang dapat dilakukan oleh perguruan tinggi adalah pembentukan watak dan karakter, pengetahuan, keterampilan, sikap dan perilaku mahasiswa. Perguruan Tinggi berperan penting dalam meningkatkan pemahaman mahasiswanya terhadap perilaku yang bertanggung jawab terhadap lingkungan hidup. Program MB-KM melalui magang industri diharapkan merupakan salah satu cara bagi mahasiswa Program studi Teknik Lingkungan untuk memberikan pengalaman nyata dalam melihat permasalahan lingkungan dan membangun kesadaran diri. Oleh karena itu dapat mengajak masyarakat untuk menerapkan etika lingkungan dalam memanfaatkan sumber daya alam.

Pemilihan bentuk program MB-KM melalui magang industri termasuk program yang diminati oleh mahasiswa. Berdasarkan hasil kuisioner dari program hibah program penelitian kebijakan merdeka belajar kampus merdeka dan pengabdian masyarakat berbasis hasil penelitian dan purwarupa PTS, diperoleh data bahwa dari 8 bentuk program MBKM yang ditawarkan maka sebesar 34\% mahasiswa Program studi Teknik Lingkungan memilih magang industri, 19\% memilih pertukaran pelajar, 15\% memilih penelitian/riset, 10\% memilih kegiatan wirausaha, sisanya memilih 4 program lainnya yaitu asistensi mengajar 5\%, proyek kemanusian 7\%, studi/proyek independent $4 \%$ dan ,membangun desa 6\%, hal ini dapat dilihat pada Gambar 2 . Hasil penelitian ini sejalan dengan penelitian (Sulistiyani et al., 2022) yang sebagian besar siswanya yang diteliti juga memilih magang industri sebagai program paling diminati dari 8 (delapan) program MB-KM yang 
974 Peningkatan Pemahaman Mahasiswa Tentang Etika Lingkungan Melalui Implementasi Merdeka Belajar dan Kampus Merdeka - Laila Febrina, Kholil, Evelyn Hanaseta N, Purnomosutji Dyah Prinajati

DOI: https://doi.org/10.31004/edukatif.v4i1.1941

ditawarkan. Hal ini sangat beralasan, karena mahasiswa ingin mendapatkan pengalaman riil di dunia kerja. Keberadaan kebijakan MBKM yang dikeluarkan oleh pemerintah melalui Permendikbud Nomor 3 Tahun 2020 tentang Standar Nasional Pendidikan Tinggi bukan menjadi hal yang sepenuhnya baru. Pengalaman mahasiswa dalam menjalankan kegiatan serupa MBKM membuat tingkat ketertarikan tinggi terhadap proses Magang industri.

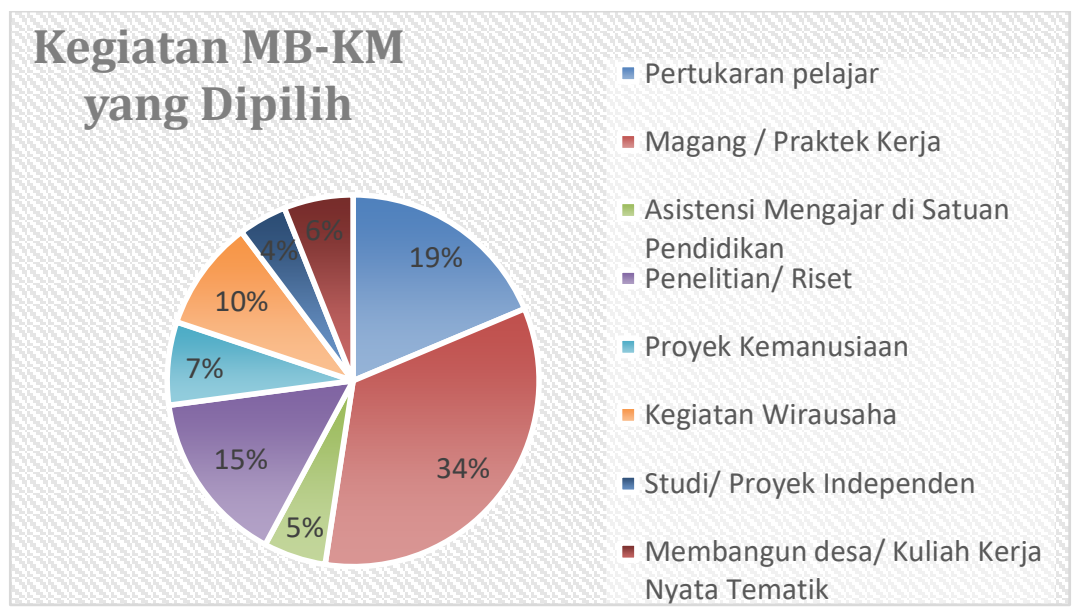

Gambar 2: Bentuk Program MB-KM yang Diminati Mahasiswa

Program MBKM yang telah dilaksanakan di Prodi Teknik Lingkungan Universitas Sahid adalah magang industri. Kegiatan magang industri merupakan kegiatan pembelajaran di luar kampus atau di lapangan yang melibatkan mahasiswa, perguruan tinggi dan juga industri (Fatah, 2021). Magang Industri juga merupakan suatu latihan yang dirancang secara cermat untuk menciptakan suatu pengalaman kerja tertentu bagi mahasiswa, yang dilakukan dalam suasana belajar. Dengan melaksanakan Magang Industri, mahasiswa dilatih untuk mengenal atmosfer dunia kerja, memberi ruang dan kesempatan untuk mengaplikasikan teori dan berpraktek serta mendekatkan mahasiswa kepada user. Keberadaan magang industri dapat mempercepat pencapaian capaian pembelajaran di Prodi Teknik Lingkungan, Sebanyak 74,38\% mahasiswa menyatakan bahwa dengan program MBKM akan mendapatkan kompetensi tambahan yang berguna di dunia kerja kelak. 25,62\% mahasiswa mengatakan sangat tergantung dengan mitra yang mendampingi. Keberhasilan program magang ini sangat dipengaruhi oleh industri mitra, hal ini karena magang industri pada program MBKM mewajibkan mahasiswa untuk belajar di industri mitra selama enam bulan (Fatah, 2021). Magang merupakan awal mula dari perjalanan mahasiswa tentang pekerjaan yang dijalaninya, sudut padang serta suasana baru yang tidak mereka peroleh saat di bangku kuliah. Agar kegiatan magang di industri dapat berkesinambungan perlu mekanisme strategi yang efektif, produktif dan efisien, yang dapat diperoleh dari industri. Hal ini memudahkan perguruan tinggi dalam memperkuat keberhasilan magang industrinya.

Hal ini menunjukkkan bahwa pelaksanaan MBKM di prodi Teknik lingkungan telah sejalan dengan tujuan utama program MB-KM yaitu untuk untuk meningkatkan kompetensi lulusan, baik soft skills maupun hard skills, agar lebih siap dan relevan dengan kebutuhan zaman, menyiapkan lulusan sebagai pemimpin masa depan bangsa yang unggul dan berkepribadian. Pengalaman magang juga dapat meningkatkan kedewasaan mahasiswa, terbiasa berada dalam situasi kewajiban dan tantangan pekerjaan. Hasil evaluasi pada mahasiswa yang telah melakukan program Magang Industri menunjukan bahwa secara keseluruhan mahasiswa mengalami peningkatan pengetahuan terhadap dunia kerja Disamping itu juga terungkap bahwa pelaksanaan MBKM dapat meningkatkan rasa percaya diri pada mahasiswa sebagai mana pada diagram berikut ini. 

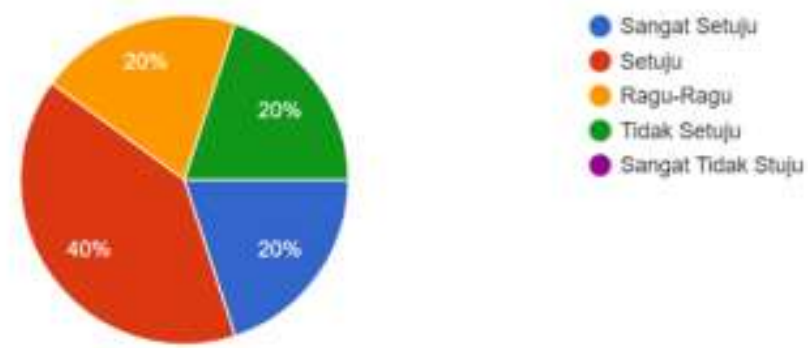

\section{Gambar 3 : Pelaksanaan Magang Industri Meningkatkan Kepercayaan Diri}

Diagram diatas menunjukkan bahwa sebagian besar mahasiswa (60\%) menyatakan kepercayaan dirinya meningkat untuk menghadapai dunia riil yang dihadapi ketika bekerja karena telah memiliki pengalaman selama magang industri. Hal ini sejalan dengan hasil penelitian (Nehe, 2021). Dalam kajian lain dikatakan bahwa bahwa pengalaman belajar dalam hal ini magang industri dapat melengkapi pembelajaran di kelas dan metode tersebut tidak hanya meningkatkan motivasi pelajar tetapi meningkatkan pemahaman materi jangka panjang dan menyebabkan rasa pencapaian diri yang lebih besar (Sembiring et al., 2020).Rasa percaya diri yang muncul pada diri mahasiswa dapat membuat dirinya berkembang ke arah yang lebih profesional dalam bidang yang ditekuninya kelak.

Program MBKM-Magang Industri yang telah dilaksanakan Program Studi Teknik Lingkungan Universitas Sahid dilakukan pada semester 6 (enam). Mengingat kegiatan magang pada MBKM ini dapat diakui sebagai bentuk pembelajaran sebesar 20 sks, maka perlu ada persiapan dan kolaborasi dengan mitra. Hasil evaluasi pada mahasiswa yang telah melakukan program Magang Industri menunjukan bahwa secara keseluruhan mahasiswa (100\%) sangat setuju dan setuju bahwa dengan Program MBKM dapat meningkatkan pengetahuan mahasiswa tentang dunia kerja kelak. (Gambar: 4). Ketika kita magang kita jadi lebih dapat mengetahui secara menyeluruh kegiatan di perusahaan, seperti membuat laporan, dan lain-lain. Secara khusus tujuan magang adalah: 1) Meningkatkan kemampuan untuk menerapkan pengetahuan dan ketrampilan yang dimiliki. 2) Meningkatkan pengetahuan dalam kerja baik dalam hal keilmuan maupun pengalaman kerja. 3) Meningkatkan kemampuan berkomunikasi dengan orang-orang yang berada satu perusahaan dengan kita. 4) Memacu motivasi mahasiswa untuk menjadi tenaga kerja yang siap kerja dan menerapkan materi yang pernah dipelajari kedalam dunia pekerjaan. 5) Membuka peluang untuk memperoleh pengalaman praktis dalam kerja bagi mahasiswa. 6) Menciptakan keterkaitan dan kesepadanan antara perguruan tinggi dengan dunia kerja. 7) Memberi hubungan kerja sama yang baik antara universitas dengan dunia usaha. Karena pasti dari adanya hubungan baik perusahaan terhadap universitas akan menghasilkan hal yang saling menguntungkan dan menghasilkan hal yang positif untuk kedepannya (Lutfia \& Rahadi, 2020). Kedepannya diharapkan mahasiswa memiliki kesiapan untuk menghadapi dunia kerja. Kesiapan kerja yang tinggi dipengaruhi oleh berbagai aspek. Faktor-faktor yang mempengaruhi kesiapan kerja bersumber dari dalam diri individu (intern) dan luar diri individu (ekstern). Faktor yang terdapat dari dalam diri individu antara lain kemampuan intelegensi, bakat, minat, motivasi, sikap, pengalaman, keterampilan dan faktor yang terdapat dari luar individu antara lain masyarakat, keluarga, sekolah dan lingkungan sekitar.

Program MB-KM melalui Magang Industri memiliki respon yang positif dalam hal memberikan gambaran dunia kerja secara hardskill dan softskill. Jenis soft skill yang dibutuhkan oleh setiap mahasiswa adalah kemampuan keterampilan 4C yang terdiri dari komunikasi (Communication), kerjasama (Collaboration), berpikir kritis dan penyelesaian masalah (Critical Thinking and Problem Solving), serta kreativitas dan inovasi (Creativity and Innovation) hal ini sangat dibutuhkan dalam menghadapi kehidupan di lingkungan masyarakat abad 21 dimana perkembangan dan inovasi teknologi menjadi faktor dalam perubahan 
976 Peningkatan Pemahaman Mahasiswa Tentang Etika Lingkungan Melalui Implementasi Merdeka Belajar dan Kampus Merdeka - Laila Febrina, Kholil, Evelyn Hanaseta N, Purnomosutji Dyah Prinajati

DOI: https://doi.org/10.31004/edukatif.v4i1.1941

pada kehidupan bermasyarakat (Sholiha \& Kurniawan, 2022). Aspek 4C inilah yang diterima oleh mahasiswa Program Studi Teknik Lingkungan ketika mereka melaksanakan magang industri. Kemampuan hardskill bisa disebut juga dengan keterampilan teknis yang melekat atau dibutuhkan untuk profesi seorang Teknik Lingkungan. keterampilan, Selama magang, mahasiswa akan mendapatkan hard skills (keterampilan, complex problem solving, analytical skills,dsb). Berdasarkan penelitian (Rizki et al., 2018) kemampuan hardskill siswa akan meningkat setelah mengikuti kegiatan magang industri. Aspek terpenting di dalam menjalani magang adalah untuk menghasilkan mahasiswa yang lebih siap menjalani dunia pekerjaan dan profesional, yang dilakukan dengan kegiatan magang, kegiatan magang ini mengarahkan kepada mahasiswa guna untuk membentuk kepribadian dan kompetensi mahasiswa. Jadi, setelah mahasiswa lulus \& telah mengikuti program magang diharapkan mereka bisa memiliki keterampilan \& kompetensi kepribadian (Lutfia \& Rahadi, 2020).
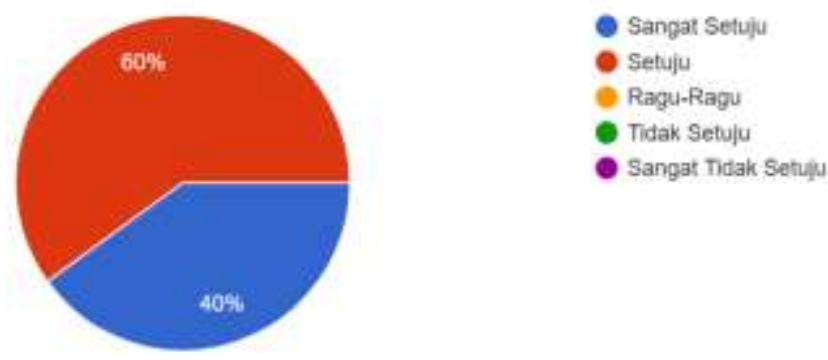

\section{Gambar 4: Meningkatkan pengetahuan tentang dunia kerja}

Salah satu problem yang dihadapai oleh lulusan mahasiswa baru adalah terbatasnya jejaring dunia kerja. Pelaksaan MBKM ini memperluas mahasiswa untuk membangun jejaring di dunia kerja. Seperti diungkap oleh sebagian besar mahasiswa (80\%), yang menyatakan bahwa melalui kegiatan MBKM, mereka dapat menjalin hubungan dengan dunia industri, baik secara langsung dengan tempat magang maupun relasi dari tempat magang. Pada awalnya mahasiswa yang mengikuti magang industri mengalami rasa canggung memasuki dunia yang sangat baru dari mereka, tetapi seiring berjalannya waktu hal itu dapat mereka atasi. Keuntungan dari program magang industri serta program MBKM lainnya, adalah dapat memperluas jejaring mahasiswa untuk dunia kerja kelak. Semakin banyak relasi dalam lingkungan profesional, mahasiswa akan mendapatkan lebih banyak kesempatan untuk belajar keahlian dalam suatu bidang,Dampak tidak terstruktur dari program Magang Industri adalah memperluas jejaring dengan bidang yang sesuai program studi yang diikuti. Sebanyak 60\% mahasiswa setuju dengan dampak memperluas jejaring, $20 \%$ sangat setuju dan $20 \%$ tidak setuju (Gambar:5).

Pada prakteknya di lapangan, mitra magang industri memiliki klasifikasi bidang yang berbeda-beda, sehingga masing-masing mahasiswa memiliki pengalaman yang spesifik. Saat ini mahasiswa tidak memiliki standar kemampuan softskill untuk menjalani program magang industri, sehingga cara mahasiswa dalam mengatasi permasalahan dan pembawaan saat bekerja pun berbeda. Beberapa mahasiswa memiliki kendala dalam berkomunikasi, lama beradaptasi, dan menangani ekspektasi diri. Tentu saja untuk menangani hal ini perlu koordinasi yang intens antara mahasiswa, pihak kampus dan pihak industri. Hal ini sejalan dengan penelitian (Fatah, 2021) jika kualitas pembimbing lapangan juga diperlukan, tanpa perhatian dan tersedianya waktu yang cukup maka peserta magang tentu akan kesulitan belajar di industri.

Namun beberapa mahasiswa dianggap berhasil ditujukan dengan adanya mitra industri yang langsung menyerap tenaga kerja dari mahasiswa magang industri. Hal ini menunjukkan bahwa pihak industri telah memberikan kepercayaan pada mahasiswa yang magang. Keuntungan kegiatan magang industri bagi pihak user menurut (Lerman, 2019) menyebutkan setidaknya terdapat lima keuntungan bagi perusahaan yang 
977 Peningkatan Pemahaman Mahasiswa Tentang Etika Lingkungan Melalui Implementasi Merdeka Belajar dan Kampus Merdeka - Laila Febrina, Kholil, Evelyn Hanaseta N, Purnomosutji Dyah Prinajati

DOI: https://doi.org/10.31004/edukatif.v4i1.1941

membuka kesempatan magang bagi mahasiswa yaitu 1) berkontribusi pada biaya produksi maupun jasa, 2) menekan biaya penerimaan karyawan baru apabila perusahaan mampu mempertahankan sebagian besar peserta magang, 3) mengurangi biaya pelatihan bagi karyawan baru untuk mengenal alat dan lingkungan kerja, 4) menambah pengalaman perusahaan dalam melakukan program pemagangan serta 5) biaya magang merupakan bagian investasi untuk pengembangan perusahaan. Berdasarkan hasil penelitian juga dikatakan bahwa industri yang melakukan proses pemagangan dengan Pendidikan dan pelatihan dapat mengurangi pengangguran di kalangan anak muda serta dapat menggandeng tenaga terlatih ke dalam bidang pekerjaan mereka, proses pemagangan ini sudah mulai banyak diterapkan di negara Australia dan Inggris (Lerman, 2019). Hal ini sejalan dengan tujuan Merdeka Belajar Kampus Merdeka adalah mendorong mahasiswa dalam menguasai berbagai bidang ilmu pengetahuan dengan bidang keahliannya, sehingga siap bersaing dalam dunia global.Industri akan mendapatkan talenta yang bila cocok nantinya bisa langsung direkrut sehingga mengurangi biaya recruitment dan training awal/induksi. Mahasiswa yang sudah mengenal tempat kerja tersebut akan lebih paham dalam memasuki dunia kerja dan kariernya.
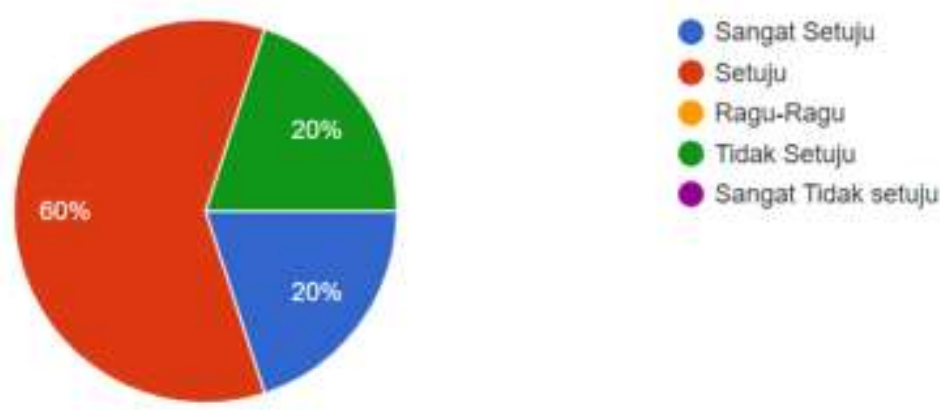

\section{Gambar 5: Magang Industri Memperluas Jejaring}

Bagi Program Studi Teknik Lingkungan, kegiatan magang industri juga sangat bermanfaat untuk, diantaranya 1)terjalinnya kerjasama atau hubungan baik antara Universitas ataupun Program Studi dengan perusahaan tempat mahasiswa magang, 2) Universitas maupun program studi dapat meningkatkan kualitas lulusannya melalui pengalaman kerja Magang, 3) universitas maupun program studi akan lebih dikenal di dunia industri. Di sisi lain implementasi MB-KM ini juga sangat bermanfaat untuk memberikan masukan untuk pengelolaan prodi dalam mencapai learning outcome-nya (LO). Melalui kegiatan magang industry ini, permasalahan industri akan tersampaikan ke perguruan tinggi sehingga memberikan kesempatan program studi untuk meng-update bahan ajar dan pembelajaran dosen serta topik-topik riset di perguruan tinggi akan makin relevan. Hal ini disampaikan sebanyak 60\% mahasiswa setuju dan sangat setuju bahwa pelaksanaan MBKM mendukung learning outcome dari prodi Teknik Lingkungan (Gambar 6). Adapun mahasiswa yang mengalami kendala antara program magang dan Learning Outcome Program Studi Teknik Lingkungan diluar kendali Program Studi seperti pergeseran atau perubahan jadwal proyek sehingga ekspektasi mahasiswa dapat belajar satu bidang secara utuh ternyata tidak tercapai dan mitra yang saat jadwal magang memiliki jenis pekerjaan yang kurang variatif. 

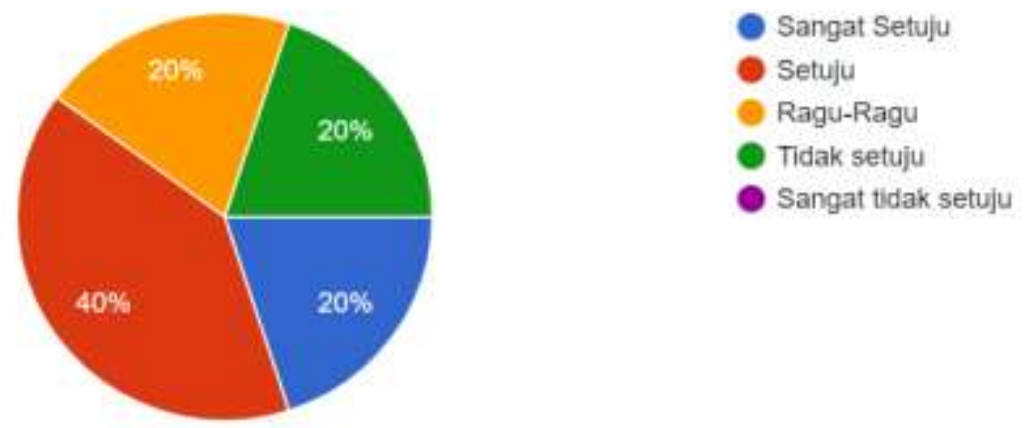

\section{Gambar 6: Magang Industri Membantu Pencapaian Learning Outcome}

Pada perkembangan di sektor industri dewasa ini sudah tentu memberikan dampak terhadap berbagai perubahan dibidang kehidupan baik bermasyarakat maupun bernegara. Perindustrian di Indonesia berkembang pesat dan mampu menghasilkan produk-produk yang bersaing di pasar dunia, seperti mesin-mesin industri, logistik, bahan kimia dan lain-lain. Dalam perindustrian tersebut masalah yang selalu timbul adalah kecelakaan kerja, penyakit akibat kerja dan dampak negatif industri terhadap lingkungan. Sehingga dalam menjalankan kegiatan magang, mahasiswa dari prodi Teknik Lingkungan, beberapa ada yang terjun ke lapangan untuk melaksanakan kegiatan sampling kualitas lingkungan. Konsep triple helix merupakan jalinan peran kerjasama ketiga aktor dalam penciptaan pengetahuan (knowledge creation) yang terdiri Akademisi, Bisnis dan Pemerintah (Haq \& Laila, 2019). Konsep ini tentu saja mendorong pihak akademisi dalam hal ini mahasiswa sebagai pelaku magang industri untuk lebih mengetahui konsep keberlanjutan lingkungan, aplikasi dari teori di bangku kuliah dengan di dunia industri.Hal ini tentu sejalan dengan konsep MB-KM yang ingin menghubungkan link and match antara dunia akademisi dengan dunia industri. Tentu saja hal ini akan sangat menentukan dari kurikulum yang telah dirancang oleh program studi. Pemahaman tentang dunia kerja ini terkadang tidak sesuai dengan kenyataan yang ada, banyak bidang-bidang pembangunan yang memerlukan tenaga professional tidak dapat dicukupi oleh output pendidikan yang ada (Suyanto et al., 2019). Karena itu masukan dari industry akan sangat dibutuhkan bagi perguruan tinggi dalam merancang kurikukumnya.

Pada pelaksanaan program magang industri yang telah dilaksanakan oleh mahasiswa Program studi Teknik Lingkungan di masa pandemi Covid-19, hanya 60\% mahasiswa yang memiliki kesempatan studi lapangan. Sedangkan $40 \%$ berada di rutinitas kantor seperti pengolahan data, mengerjakan laporan, dan membantu administrasi mitra. Pemilihan mitra juga mempengaruhi ada tidaknya studi lapangan secara langsung. Beberapa mitra yang bekerja sama dalam program magang memang memiliki aktivitas kegiatan perkantoran saja karena lokasi/site kerja berada di luar kota.

Dengan magang industri, mahasiswa yang sebelumnya hanya mengetahui tentang kualitas lingkungan dari tataran teoritis, maka ketika melaksanakan magang industri, dapat menambah soft skill mereka tentang pengujian kualitas lingkungan. Pengetahuan tentang Kualitas Lingkungan dalam pembelajaran didapatkan secara teori, sedangkan dalam program MBKM- Magang Industri telah tersampaikan dengan praktek dan aplikasi di dunia kerja. Secara umum, mahasiswa memberikan respon positif mengenai aplikasi pengetahuan selama masa kuliah dengan kesempatan Magang industri. Dengan pelaksanaan magang industri ini, mahasiswa menjadi merasa lebih siap menghadapi dunia kerja. Hal ini sejalan dengan penelitian (Suyanto et al., 2019) yang menunjukkan bahwa pengalaman magang berpengaruh signifikan terhadap kesiapan kerja. 


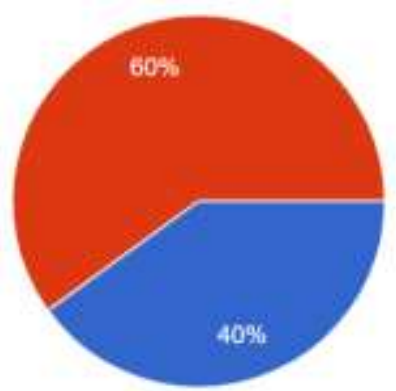

Sangat setuju

Setuju

Ragu-Ragu

Tidak Setuju

Sangat Tidak Setuju

\section{Gambar 7: Magang Industri Menambah ketrampilan pengujian kualitas lingkungan}

Pembangunan berwawasan lingkungan yang berkelanjutan (sustainable) dapat tercipta dari perilaku berwawasan lingkungan dari masyarakat, tetapi pada kenyataannya pencemaran lingkungan pada banyak faktor didominasi oleh manusia.Kondisi lingkungan tidak terlepas dari aktivitas domestik rumah tangga sehari-hari. Limbah rumah tangga yang dihasilkan mengandung detergen dari bekas cucian, ammonia serta bahan kimia lainnya.Apabila limbah tersebut terbuang ke lingkungan tentu akan terakumulasi dalam jumlah yang banyak di lingkungan yang dapat melebihi batas ambang baku mutu yang diperbolehkan. Hal ini tentu saja merusak kelestarian lingkungan. Untuk itu sangat diperlukan adanya pehaman dari publik terkait etika lingkungan. Pencemaran lingkungan umumnya disebabkan oleh masyarakat di lingkungannya itu sendiri. Dari pencemaran yang ada, hal ini dapat diketahui dari uji sampling lingkungan yang dilakukan oleh mahasiswa saat mereka magang. Dari hasil pengujian ini, mahasiswa jadi mempelajari secara langsung faktor penyebab pencemaran lingkungan, yang salah satunya adalah rendahnya pemahaman masyarakat terkait etika lingkungan. Publik akan sangat mudah membuang limbahnya ke badan air, karena beranggapan badan air sebagai tempat sampah besar bagi mereka. Mahasiswa sebagai agen perubahan dari suatu pembangunan dan kelestarian lingkungan dapat berperan serta dalam hal ini.

Tata nilai yang menyebabkan meningkatnya pencemaran dan perusakan lingkungan adalah masih dianutnya etika lingkungan yang anthropocentric. Etika ini menempatkan kepentingan manusia di atas kepentingan makhluk lainnya (Nurhayati, 2020). Etika sebenarnya sudah melekat dalam diri seseorang sejak lahir, tetapi belakangan ini etika tidak muncul, walau kebijakan lingkungan sudah ada tetapi degradasi lingkungan juga semakin meningkat. Munculnya kerusakan ini karena etika lingkungan tidak pernah dikedepankan. Untuk itu perlu dibanguan kepedulian manusia terhadap lingkungan. Kepedulian manusia untuk menjunjung keberlanjutan hidup dan alam yang tercermin dalam nilai-nilai kearifan lokal yang menjunjung konsep pemeliharaan lingkungan, mulai pudar seiring dengan meningkatnya tuntutan hidup manusia dalam memenuhi kebutuhannya. Terkait dengan kesadaran publik dibidang etika lingkungan, hasil MBKM ini juga menambah pengetahuan mahasiswa bahwa pengembangan etika lingkungan bagi masyarakat masih rendah. Hal ini dibuktikan ketika mahasiswa melakukan kegiatan di lapangan,sebagai tugas dari tempat magang untuk melakukan kualitas lingkungan Etika lingkungan ini adalah sikap kita dalam menjaga kelestarian alam ini agar alam ini tidak rusak, baik ekosistem maupun habitatnya. Untuk diperlukan peningkatan pemahaman etika lingkungan. Hal ini sejalan dengan penelitian yang telah dilakukan oleh (Nurhayati, 2020).

Pengetahuan tentang Kualitas Lingkungan dalam pembelajaran didapatkan secara teori, sedangkan dalam program MBKM- Magang Industri telah tersampaikan dengan praktek dan aplikasi di dunia kerja. Secara umum, mahasiswa memberikan respon positif mengenai aplikasi pengetahuan selama masa kuliah dengan kesempatan Magang industri. Banyaknya permasalahan lingkungan diluar kampus, memberikan kesadaran bagi mahasiswa program studi Teknik lingkungan khususnya yang melaksanakan kegiatan magang industri untuk meningkatkan kesadaran mahasiswa tentang permasalahan lingkungan,.melihat lingkungan 
980 Peningkatan Pemahaman Mahasiswa Tentang Etika Lingkungan Melalui Implementasi Merdeka Belajar dan Kampus Merdeka - Laila Febrina, Kholil, Evelyn Hanaseta N, Purnomosutji Dyah Prinajati

DOI: https://doi.org/10.31004/edukatif.v4i1.1941

sebagai rumahnya sendiri yang perlu dirawat dan dijaga kelestariannya. Bentuk pembelajaran melalui magang industri ini sangat efektif dalam membangun kesadaran di bidang lingkungan. Hal ini sejalan dengan penelitian (Mustari et al., 2017). Bentuk pembelajaran langsung dengan mitra industri meningkatkan sensitivitas mahasiswa terhadap isu lingkungan karena banyak studi kasus yang dialami dan dianalisa sebabakibat serta penanganan kedepannya. Sensitivitas lingkungan dapat meningkatkan kreativitas mahasiswa (Etni Marliana et al., 2021). Kreatifitas dapat membbuat siswa membuat kerajianan dari limbah disekitar sehingga menjadi nilai yang bermanfaat. Perlu kita sadari bahwa kita ini juga bagian dari alam ini. Maka kita harus menjaga lingkungan ini dengan baik dengan norma- norma etika lingkungan.

Program Magang industri meningkatkan pengetahuan mahasiswa terhadap pencemaran lingkungan serta baku mutu terkait jenis kegiatan masing-masing mitra. Hal ini sejalan dengan penelitian (Kastawaningtyas, A., 2017) bahwa kegiatan experiential learning dapat meningkatkan pengetahuan siswa. Salah satu kegiatan mahasiswa adalah pelaporan kegiatan Magang, mahasiswa melakukan eksplorasi pengetahuan terkait mitra terutama bidang/ divisi Magang sehingga peraturan atau baku mutu yang dipakai lebih variatif terutama pada mitra dengan lokasi kerja di luar kota atau standar penilaian lingkungan versi terbaru (perubahan). Berdasarkan pernyatan tersebut, mahasiswa melihat perlunya edukasi kepada masyarakat tentang etika lingkungan untuk menjamin kelestarian lingkungan, hal ini sejalan dengan penelitian yang dilakukan oleh (NUR AFRINA. NW, 2020) etika lingkungan merupakan hal baru di masyarakat luas, bahkan dalam lingkup internasional (Hudha \& Husamah, 2019), sehingga edukasi terhadap etika lingkungan harus terus ditingkatkan agar masyarakat tersadarakan melalui agent perubahannya adalah mahasiswa. Sehingga sangat penting pembekalan pengetahuan tentang keberlanjutan lingkungan dipahami oleh mahasiswa. Pengetahuan tersebut dapat diperoleh secara teori di bangku kuliah dan dapat diperoleh dari dampak positif program MBKm melalui magang industri.

\section{KESIMPULAN}

Implementasi MBKM melalui magang industri di bidang lingkungan dapat meningkatkan pemahaman mahasiswa tentang persoalan-persoalan lingkungan, Mahasiwa memiliki respon positif dengan adanya program Magang Industri- MBKM, hal ini dilandasi oleh sadarnya mahasiswa akan ilmu pengetahuan yang tidak didapatkan utuh hanya dengan perkuliahan. Implementasi MBKM melalui magang industri juga meningkatkan percayaan diri dan perluasan jejaring di dunia industri. Bagi Program Studi Teknik Teknik Lingkungan Universitas Sahid implementasi MBKM membantu pencapaian learning outcome.Sebagai saran dari hasil kajian ini, implementasi MBKM perlu dirancang dengan melibatkan dunia industri agar pelaksanaan kegiatan sesuai dengan kurikulum yang dikembangkan di Program Studi masing-masing.

\section{UCAPAN TERIMA KASIH}

Terima kasih kepada Kementerian Pendidikan, Kebudayaan, Riset, dan Teknologi atas Bantuan pendanaan program penelitian kebijakan mereka belajar kampus merdeka dan pengabdian masyarakat berbasis hasil penelitian dan purwarupa PTS.

\section{DAFTAR PUSTAKA}

Budianta, D. (2010). Pentingnya Etika Lingkungan Untuk Meminimalkan Global Warming. Psl Universitas Sriwijaya.

Dirjen Dikti Kemendikbud. (2020). Buku Panduan Pelayanan Merdeka Belajar Dan Kampus Merdeka. 
981 Peningkatan Pemahaman Mahasiswa Tentang Etika Lingkungan Melalui Implementasi Merdeka Belajar dan Kampus Merdeka - Laila Febrina, Kholil, Evelyn Hanaseta N, Purnomosutji Dyah Prinajati

DOI: https://doi.org/10.31004/edukatif.v4i1.1941

Merdeka Belajar-Kampus Merdeka, 1-33. Http://Dikti.Kemdikbud.Go.Id/WpContent/Uploads/2020/04/Buku-Panduan-Merdeka-Belajar-Kampus-Merdeka-2020

Etni Marliana, Gilang Puspita Rini, \& Faridhatun Faidah. (2021). Pelatihan Untuk Meningkatan Semangat Green Entrepreneur Pada Siswa Sekolah Menengah Atas. Jurnal Solma, 10(1), 42-51. Https://Doi.Org/10.22236/Solma.V10i1.5348

Fatah, A. (2021). Prosiding Seminar Nasional Teknologi Pembelajaran Universitas Negeri Malang Tahun 2021. In I. Sigit Dwi Laksana, Universitas Muhammadiyah Ponorogo, I. Yuli Ani Setyo Dewi, Stitnu Al Hikmah Mojokerto, I. Faizuddin Harliansyah, Universitas Islam Negeri Maulana Malik Ibrahim Malang, I. Dian Arief Pradana, Universitas 17 Agustus 1945 Banyuwangi, \& I. Moch Desta Pradana, Iain Kediri (Eds.), Eksplorasi Dukungan Industri Mitra Dalam Pelaksanaan Magang Pada Program Merdeka Belajar Kampus Merdeka (Pp. 1-9). Http://Snastep.Com/Proceeding/Index.Php/Snastep/Index

Fuadi, T. M. (2021). Prosiding Seminar Nasional Biotik Konsep Merdeka Belajar-Kampus Merdeka (Mbkm) : Aplikasinya Dalam Pendidikan Biologi. Prosiding Seminar Nasional Biotik.

Haq, I. S., \& Laila, L. (2019). Pola Penyelenggaraan Konsep Triple Helix Dalam Penyediaan Sumber Daya Manusia Pengelola Pabrik Kelapa Sawit Indonesia. Jurnal Vokasi Teknologi Industri (Jvti), 1(1), 37-46. Https://Doi.Org/10.36870/Jvti.V1i1.44

Hasir, \& Rofiqi, I. (2017). Pentingnya Etika Lingkungan Dalam Melestarikan Sumber Daya Alam. December, $46-51$.

Https://D1wqtxts1xzle7.Cloudfront.Net/59871353/Etika_Lingkungan_Dengan_Partisipasinya_Dalam_P elestarian_Lingkungan_120190626-47572-D30bjt-With-Cover-Page-

V2.Pdf?Expires=1638882725\&Signature=Iizdjw7ach5hezsxpcsqsspwy9qti9vmesbdcjlt7vesymckpqdyik g9nosong0te

Hudha, A. M., \& Husamah, H. (2019). Ethics Of Domestic Tourist To Beach Conservation (Case Study Of Balekambang Beach, Malang District). Jurnal Pengelolaan Sumberdaya Alam Dan Lingkungan (Journal Of Natural Resources And Environmental Management), 9(1), 9-16. Https://Doi.Org/10.29244/Jps1.9.1.9-16

Julius, P., \& Nagel, F. (2020). Etika Lingkungan Hidup. Teknologi Kebumian Dan Kealautan, 42, 521-525. Https://Doi.Org/Https://Doi.Org/10.31284/P.Semitan.2020.1004

Kastawaningtyas, A., \& M. (2017). Peningkatan Keterampilan Proses Sains Siswa Melalui Model Experiential Learning Pada Materi Pencemaran Lingkungan. Jurnal Penelitian Pendidikan Ipa, 2(2), 45-52. Https://Doi.Org/Https://Doi.Org/10.26740/Jppipa.V2n2.P45-52

Lerman, R. (2019). Do Firms Benefit From Apprenticeship Investments? Iza World Of Labor, May 2014, 1 11. Https://Doi.Org/10.15185/Izawol.55.V2

Lutfia, D. D., \& Rahadi, D. R. (2020). Analisis Internship Bagi Peningkatan Kompetensi Mahasiswa. Jurnal Ilmiah Manajemen Kesatuan, 8(3), 199-204. Https://Doi.Org/10.37641/Jimkes.V8i3.340

Mariati, M. (2021). Tantangan Pengembangan Kurikulum Merdeka Belajar Kampus Merdeka Di Perguruan Tinggi. Seminar Nasional Teknologi Edukasi Sosial Dan Humaniora, 1(1), 749-761.

Muhammad Rizki, G., Bintoro, A., \& Hilmanto, R. (2016). Perbandingan Emisi Karbon Dengan Karbon Tersimpan Di Hutan Rakyat Desa Buana Sakti Kecamatan Batanghari Kabupaten Lampung Timur. Jurnal Sylva Lestari, 4(1), 89. Https://Doi.Org/10.23960/Jsl1489-96

Muhammad Taufik Awaludin, E. S. (2017). Penerapan Model Pembelajaran Inkuiri Bebas Dan Peta Konsep Untuk Meningkatkan Pemahaman Pencemaran Lingkungan Dan Kemampuan Mahasiswa Dalam Memecahkan Masalah Lingkungan. Jurnal Pendidikan Lingkungan Hidup, 5(2), 18-22. Https://Repository.Unpak.Ac.Id/Tukangna/Repo/File/Files-20170926125041.Pdf

Mustari, M., Sudana, I. M., \& Supraptono, E. (2017). Model Teaching Factory Bagi Pembelajaran Merencana 
982 Peningkatan Pemahaman Mahasiswa Tentang Etika Lingkungan Melalui Implementasi Merdeka Belajar dan Kampus Merdeka - Laila Febrina, Kholil, Evelyn Hanaseta N, Purnomosutji Dyah Prinajati

DOI: https://doi.org/10.31004/edukatif.v4i1.1941

Dan Menginstalasi Sistem Audio. Journal of Vocational And Career Education, 2(2). Https://Doi.Org/10.15294/Jvce.V2i2.13878

Muthoharoh, V., \& Sakti, N. C. (2021). Media Pembelajaran Interaktif Menggunakan Adobe Flash Cs6 Untuk Pembelajaran Ips Siswa Sekolah Menengah Atas. Edukatif: Jurnal Ilmu Pendidikan, 3(2), 364-375. Https://Doi.Org/10.31004/Edukatif.V3i2.315

Nehe, B. M. (2021). Analisis Konsep Implementasi Merdeka Belajar - Kampus Merdeka Dalam Mengahadapi Era Revolusi Industri 4.0 Di Masa Pendemik Di Stkip Setia Budhi Rangkasbitung 2021. Prosiding Seminar Nasional Setiabudhi, $\quad 1(1), \quad 13-19$. Https://Jurnal.Stkipsetiabudhi.Ac.Id/Index.Php/Prosiding/Article/View/18

Nur Afrina. Nw. (2020). Menjaga Kelestarian Lingkungan Dalam Perspektif Islam (Edukasi Ajaran Islam Tentang Lingkungan Hidup Di Desa Mangunharjo, Kecamatan Jatipurno, Kabupaten Wonogiri) (Issue September). Institut Agama Islam Negeri Ponorogo.

Nurhayati, M. Y. S. Y. (2020). Paradigma Filsafat Etika Lingkungan Dalam Menentukan Arah Politik Hukum Lingkungan. Al-Adl: Jurnal Hukum, Xii(July), 1-23. Https://Ojs.UniskaBjm.Ac.Id/Index.Php/Aldli/Index

Purwanto, N. (2018). Perilaku Sadar Lingkungan Pemukim Bantaran Sungai Jelai, Kabupaten Sukamara. Jurnal Pembangunan Wilayah \& Kota, 14(1), 41. Https://Doi.Org/10.14710/Pwk.V14i1.17348

Rizki, N. A., Suyadi, B., \& Sedyati, R. N. (2018). Pengaruh Praktik Kerja Industri Terhadap Kemampuan Penguasaan Hardskill Siswa Kelas Xi Program Keahlian Teknik Komputer Dan Jaringan Smk Negeri 5 Jember Tahun Ajaran 2016/2017. Jurnal Pendidikan Ekonomi: Jurnal Ilmiah Ilmu Pendidikan, Ilmu Ekonomi Dan Ilmu Sosial, 11(2), 89. Https://Doi.Org/10.19184/Jpe.V11i2.6452

Rusli Baharuddin, M. (2021). Adaptasi Kurikulum Merdeka Belajar Kampus Merdeka (Fokus: Model Mbkm Program Studi). Jurnal Studi Guru Dan Pembelajaran, 4(1). Https://Doi.Org/10.30605/Jsgp.4.1.2021.591

Saihu, S., \& Mailana, A. (2019). Teori Pendidikan Behavioristik Pembentukan Karakter Masyarakat Muslim Dalam Tradisi Ngejot Di Bali. Ta'dibuna: Jurnal Pendidikan Islam, 8(2), 163. Https://Doi.Org/10.32832/Tadibuna.V8i2.2233

Samidjo, S. (2017). Efektifitas Pelaksanaan Magang Industri Mahasiswa Program Studi Pendidikan Teknik Mesin. Taman Vokasi, 2(2), 246. Https://Doi.Org/10.30738/Jtvok.V5i2.2528

Sembiring, V. A., Rahayu, N., \& Tarigan, E. (2020). Persepsi Dan Kepuasan Mahasiswa Terhadap Program Magang Di Industri Pariwisata Luar Negeri (Studi Kasus Mahasiswa Perguruan Tinggi Pariwisata Di Jakarta). Jurnal Ilmiah Pariwisata, 25(3), 201-2014.

Sholiha, I. N., \& Kurniawan, R. Y. (2022). Edukatif: Jurnal Ilmu Pendidikan Pengembangan Instrumen Penilaian Berbasis Higher Order Thinking Skills Pada Mata Pelajaran Ekonomi Sekolah Menengah Atas. 4(1), 123-132. Https://Doi.Org/Prefix 10.31004/Edukatif By Crossref

Sulaeman, Supriadi, Zinnurain, Mulhidin, \& Endah Resnandari Puji Astui. (2021). Pelatihan Edukasi Sadar Lingkungan (Sidarling) Bagi Pemuda Desa Lembar Kabupaten Lombok Barat Menuju Desa Ekowisata. Pijar Mandiri Indonesia, 1(1), 9-12. Http://Lingkarpenaindonesia.Com/EJournal/Index.Php/Pmi/Article/View/9/36

Sulistiyani, E., Soleha, U., Amalia, R., Hartatik, S., \& Sisiawan, R. (2022). Implementasi Merdeka Belajar Kampus Merdeka (Mbkm) Pada Fakultas Kesehatan Dan Non Kesehatan Kesehatan. Edukatif: Jurnal Ilmu Pendidikan, 4(1), 686-698.

Suyanto, F., Rahmi, E., \& Tasman, A. (2019). Pengaruh Minat Kerja Dan Pengalaman Magang Terhadap Kesiapan Kerja Mahasiswa Fakultas Ekonomi Universitas Negeri Padang. Jurnal Ecogen, 2(2), 187. Https://Doi.Org/10.24036/Jmpe.V2i2.7311 
983 Peningkatan Pemahaman Mahasiswa Tentang Etika Lingkungan Melalui Implementasi Merdeka Belajar dan Kampus Merdeka - Laila Febrina, Kholil, Evelyn Hanaseta N, Purnomosutji Dyah Prinajati

DOI: https://doi.org/10.31004/edukatif.v4i1.1941

Telly Rosdiyani, P., Prasetyo Artiwi, N., Hendra, Y., Nasri, E., Nuraida, I., Hidayanti, N., Intan Solihati, T., Ansoriyah, S., Farhani Maulida, H., Amilia, E., Rifai, A., Surahmat, A., Dedy Fu, T., Suhendar, B., Abdi Khairusy, M., Atmaja, S., Febriani, R., Hartika, N., Krisnaningsih, E., ... Fadilla Oktaviana, Mp. (2021). Changing Trends Pendidikan Tinggi Pada Kampus Merdeka (Gagasan Konstruksi Dan Paradigma Mbkm) (M. S. Fitriyah \& M. P. Ma'ulfi Kharis Abadi, M.Pd Dr. Fadilla Oktaviana (Eds.); Cetakan 1, Pp. 1-31). Media Madani Jl. Https://Elibrary.Unikom.Ac.Id/Id/Eprint/4472/1/Mbkm_Unbaja-21-Pages-113,192-209.Pdf

Wahyudi, A., Salamun, S., Hamid, A., \& Choirudin, C. (2021). Strategi \{Pengelolaan \} \{Vocational $\{$ Life \{Skill $\} \quad\{$ Pada $\} \quad\{$ Pendidikan $\} \quad\{$ Islam $\} . \quad J m p i, \quad 6(1), \quad 39-45 . \quad$ Https://Www.EjurnalStitpringsewu.Ac.Id/Index.Php/Jmpi/Article/View/Vol06no01_6_Tahun2021

Wahyunita, I., \& Subroto, W. T. (2021). Efektivitas Model Pembelajaran Blended Learning Dengan Pendekatan Stem Dalam Upaya Meningkatkan Kemampuan Berfikir Kritis Peserta Didik. Edukatif: Jurnal Ilmu Pendidikan Volume, 3(3), 1010-1021. Https://Edukatif.Org/Index.Php/Edukatif/Index\%0aefektivitas 